\title{
MOTIVASI MAHASISWI PROGRAM STUDI PENDIDIKAN AGAMA ISLAM FAKULTAS ILMU TARBIYAH DAN KEGURUAN IAIN AMBON DALAM MENGGUNAKAN CADAR
}

\author{
Farhanah S N Fattaroeba ${ }^{1}$, Sammad Umarella ${ }^{2}$, Saddam Hussein ${ }^{3}$ \\ Program Studi Pendidikan Agama Islam FITK IAIN Ambon \\ email: nabilahfattaroeba450@gmail.com
}

\begin{abstract}
This study aims to determine the motivation and factors supporting and inhibiting student motivation in using the veil. The research in this thesis uses a mixed method which is a mixed type of research, namely a combination of qualitative and quantitative which produces data in the form of words or sentences and also produces data in the form of numbers or percentages of the observed subjects. The subjects studied were students of the Islamic Religious Education study program, Faculty of Tarbiyah and Teacher Training, IAIN Ambon, which consisted of 12 female students who still wore the veil. Data collection methods used include interviews, questionnaires and documentation. Based on the results of the study found that: The motivation of students of the Islamic Education Study Program Faculty of Tarbiyah and Teacher Training IAIN Ambon in using the veil is divided into two, namely intrinsic motivation which includes: mastery goals and need for achievement and extrinsic motivation which includes: expectations of authority from family, expectations educational authority, hope from friends and fear of failure. The supporting factors, namely: positive support from family, invitations from friends, and often watching studies related to the virtues of using the veil. There are also inhibiting factors, namely: the fear of being ostracized, as well as negative assumptions from the family regarding the veil, a less supportive living environment. Furthermore, based on the percentage count processed using quantitative analysis, it was found that the level of motivation of students of the Islamic Religious Education Study Program, Faculty of Tarbiyah and Teacher Training, IAIN Ambon, in using the veil, was in the very high category, with a value of $86.17 \%$.
\end{abstract}

\section{Keywords: Motivation, Veiled Student}

\begin{abstract}
Abstrak: Penelitian ini bertujuan untuk mengetahui motivasi serta faktor penunjang dan penghambat motivasi mahasiswi dalam menggunakan cadar. Penelitian dalam skripsi ini menggunakan jenis mixed method yang merupakan jenis penelitian campuran, yakni gabungan antara kualitatif dan kuantitatif yang menghasilkan data dalam bentuk katakata atau kalimat dan juga menghasilkan data berupa angka-angka atau persentase dari subjek yang diamati. Subjek yang diteliti ialah mahasiswi program studi Pendidikan Agama Islam Fakultas IImu Tarbiyah dan Keguruan IAIN Ambon yang terdiri sebanyak 12 orang mahasiswi yang masih menggunakan cadar. Metode pengumpulan data yang digunakan di antaranya ialah wawancara, kuesioner dan dokumentasi. Berdasarkan hasil penelitian menemukan bahwa: Motivasi Mahasiswi Program Studi Pendidikan Agama Islam Fakultas IImu Tarbiyah dan Keguruan IAIN Ambon dalam menggunakan cadar terbagi menjadi dua yaitu motivasi intrinsik yang meliputi: mastery goal dan need for achivment dan motivasi ekstrinsik yang meliputi: harapan otoritas dari keluarga, harapan otoritas pendidikan, harapan dari teman dan fear of failur. Adapun faktor penunjang, yaitu: adanya dukungan positif dari keluarga, ajakan dari teman, dan sering menonton kajian yang berkaitan keutamaan menggunakan cadar. Faktor penghambat juga, yaitu: adanya rasa was-was takut dikucilkan, serta anggapan yang negatif dari keluarga terkait cadar, lingkungan tempat tinggal yang kurang mendukung. Selanjutnya, berdasarkan hitungan persentase yang diolah menggunakan analisis kuantitatif ditemukan bahwa tingkat motivasi mahasiswi Program Studi Pendidikan Agama Islam Fakultas IImu
\end{abstract}


Tarbiyah dan Keguruan IAIN Ambon dalam menggunakan cadar, berada pada kategori sangat tinggi, dengan nilai $86,17 \%$.

Kata kunci: Motivasi, Mahasiswi Bercadar

\section{PENDAHULUAN}

Menutup aurat dari pandangan orang lain hukumnya wajib. Aurat wajib ditutup dengan pakaian yang dapat menghalangi kulit dari pandangan, baik terbuat dari kain, kulit, kertas, tumbuh-tumbuhan maupun bahan baku lain yang yang bisa digunakan sebagai penutup (Abdul Wahhab Abdus Salam Thawilah,2007:167). Dalam al-Qur'an telah dijelaskan mengenai perintah menutup aurat bagi muslimah yaitu pada surah Al-Ahzab ayat 59 yang berbunyi:

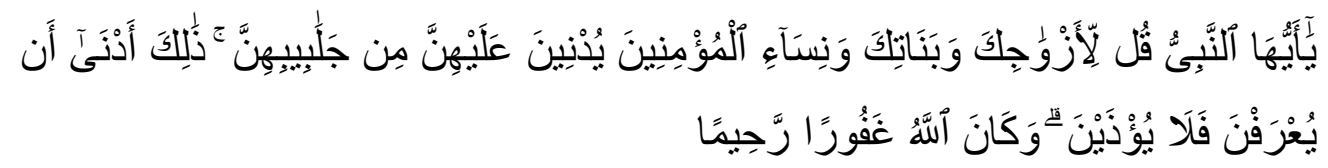

Terjemahnya: Wahai Nabi! Katakanlah kepada istri-istrimu, anak-anak perempuanmu dan istri-istri orang mukmin, "Hendaklah mereka menutupkan jilbabnya ke seluruh tubuh mereka." Yang demikian itu agar mereka lebih mudah untuk dikenali, sehingga mereka tidak diganggu. Dan Allah Maha Pengampun, Maha Penyayang.

Pada dasarnya, jilbab ialah busana muslimah terusan panjang yang menutupi seluruh badan kecuali wajah, tangan dan kaki dan itu semua terkait dengan tuntunan syariat diwajibkannya para muslimah menutup aurat (Genta Muslimah, 2020:124). Sedangkan secara etimologis jilbab berasal dari bahasa Arab 'jalaba' yang berarti menghimpun atau membawa. Istilah jilbab digunakan pada negeri-negeri berpenduduk muslim lain sebagai jenis pakaian dengan penamaan berbeda-beda. Di India dan Pakistan disebut pardeh, di Libya disebut milayat, di Irak disebut abaya, di Turki disebut charshaf, dan tudung di Malaysia, sementara di negara ArabAfrika disebut hijab (Fakta Agama, 2015:343).

Merujuk pada surah al-Ahzab ayat 59 yang terdapat kata mengenai jilbab, hal tersebut ditujukan kepada pemaknaan pada pakaian panjang dan longgar, yaitu pakaian yang tidak menonjolkan bentuk lekuk tubuh dari si pemakai. Dan pada perkembangan selanjutnya, jilbab ini kemudian memiliki posisi penting yaitu sebagai simbol identitas sekaligus resistensi (Amany Lubis, dkk,2018:138). 
Adapun kebolehan melihat auratnya seorang wanita muslim adalah pada mereka yang masih memiliki hubungan nasab atau yang disebut sebagai mahram. Sebagaimana Allah Subhanahu wa ta'ala telah berfirman dalam surah an-Nur ayat 31:

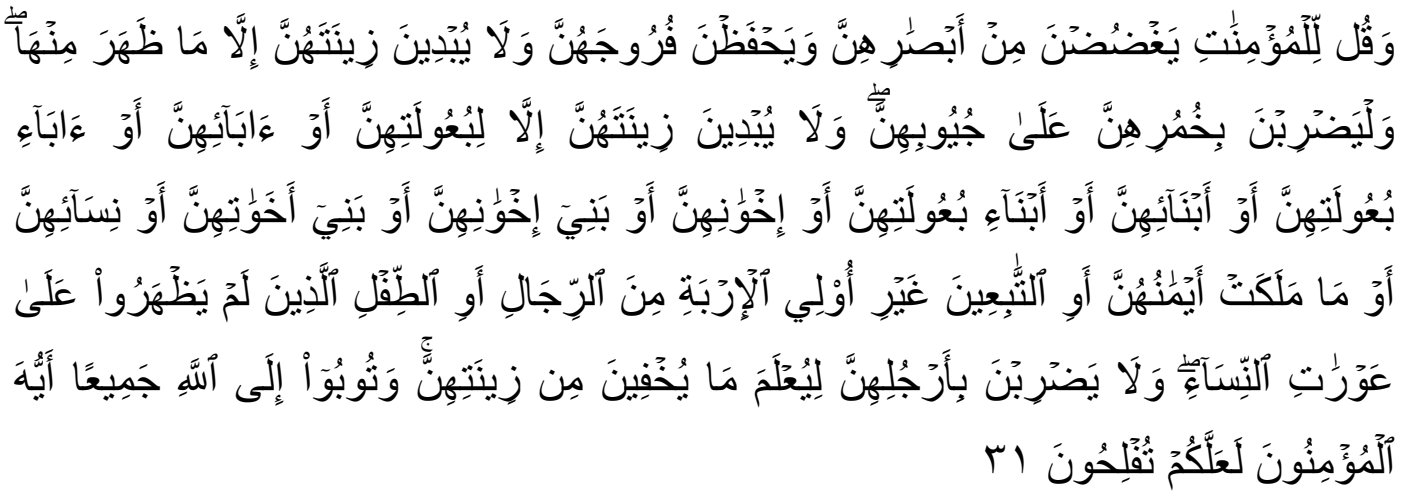

Terjemahnya: Dan katakanlah kepada para perempuan yang beriman, agar mereka menjaga pandangannya, dan memelihara kemaluannya, dan janganlah menampakkan perhiasannya (auratnya), kecuali yang (biasa) terlihat. Dan hendaklah mereka menutupkan kain kerudung ke dadanya, dan janganlah menampakkan perhiasannya (auratnya), kecuali kepada suami mereka, atau ayah mereka, atau ayah suami mereka, atau putraputra mereka, atau putra-putra suami mereka, atau saudara-saudara laki mereka, atau putra-putra saudara laki-laki mereka, atau putra-putra saudara perempuan mereka, atau para perempuan (sesama Islam) mereka, atau hamba sahaya yang mereka miliki, atau para pelayan lakilaki (tua) yang tidak mempunyai keinginan (terhadap perempuan), atau anak-anak yang belum mengerti tentang aurat perempuan. Dan janganlah mereka menghentakkan kakinya agar diketahui perhiasan yang mereka sembunyikan. Dan bertobatlah kamu semua kepada Allah, wahai orangorang yang beriman, agar kamu beruntung.

Aurat dikatakan sebagai suatu kemaluan dan semua hal yang dapat menimbulkan rasa malu apabila terlihat. Aurat merupakan perhiasan yang wajib ditutupi dari orang-orang yang tidak berhak untuk melihatnya dan atau menikmatinya (Anna Mariana,2011:15). Sama halnya dengan wajah, meskipun pada bagian ini masih menjadi perbincangan yang tiada habis-habisnya karena beberapa ulama berpendapat wajah bukanlah termasuk aurat yang wajib ditutupi, namun beberapa ulama juga berpendapat tidak ada pengharaman dalam menutup wajah. Tersebab 
wajah merupakan tempat awal di mana sesiapa saja bisa menikmatinya dengan leluasa sehingga banyaknya timbul rasa suka seseorang itu berawal dari paras yang dilihat dan sering kali dapat menjadi fitnah. Oleh karena itu, penggunaan cadar atau niqab menjadi suatu keharusan bagi wanita-wanita muslimah yang dikhawatirkan karena dari wajahnya dapat menimbulkan fitnah.

Niqab merupakan istilah syar'i untuk cadar (Ulfha, 2011:18) yaitu sejenis kain yang digunakan untuk menutupi seluruh wajah kecuali daerah mata. Dalam Kamus Besar Bahasa Indonesia, cadar diartikan sebagai kain penutup kepala atau muka (bagi perempuan) yang dikenakan oleh sebagian muslimah sebagai kesatuan dengan jilbab (hijab) (Nujood Ali dan Delphine Minoui,2019:218).

Fakultas IImu Tarbiyah dan Keguruan merupakan salah satu Fakultas yang berada di Institut Agama Islam Negeri Ambon dan sebagai lembaga yang berada di bawah naungan Departemen Agama dimana segala aturan maupun tata cara yang dipakai tentunya bercirikan keislaman. Salah satunya dalam hal berpakaian bahwasanya di IAIN Ambon menetapkan aturan bagi semua wanita muslimah harus mengenakan pakaian yang dapat menutup aurat mereka secara sempurna dari kepala sampai kaki, yakni memakai khimar/kerudung, tidak memakai celana ketat dan harus memakai kaos kaki. Aturan ini memberi dampak positif terhadap mahasiswi yang memang sadar akan pentingnya menutup aurat sebagai identitas dan kewajiban mutlak kaum wanita muslim, bahkan dengan seiring berjalannya waktu, ada yang belajar mengenakan cadar.

Kebiasaan menggunakan cadar ini pun semakin diminati para wanita muslimah. Fenomena ini terlihat pada kalangan mahasiswi di IAIN Ambon, terkhusus di Program Studi Pendidikan Agama Islam sehingga hal ini menjadikan kesan yang positif bagi orang-orang yang mengerti dan paham mengenai penggunaan cadar itu sendiri, namun akan ada 
pandangan negatif juga bagi orang-orang yang belum paham tentang cadar. Sehingga penggunaan cadar masih menjadi sesuatu yang dipandang sebelah mata oleh sebagian masyarakat atau orang-orang yang belum begitu memahami betul mengenai pentingnya penggunaan cadar.

Seringnya muncul anggapan bahwa cadar bukanlah ajaran Islam melainkan hanya sebuah budaya dari Timur Tengah, ada juga yang menganggap bahwa wanita bercadar identik dengan teroris maupun paham radikalisme, karena kerap kali dijumpai aksi terorisme yang terekspos di Indonesia selalu pelakunya dikaitkan dengan sosok agamis, kaum celana cingkrang, jenggot panjang dan jilbab bercadar, dan masih banyak yang lainnya juga sehingga menimbulkan konsep mispersepsi terhadap wanita yang menggunakan cadar, artinya adanya suatu anggapan yang berlebihan atau kurangnya pemahaman terhadap wanita yang menggunakan cadar. Anggapan-anggapan semacam itu perlu diluruskan agar tidak membuat wanita-wanita yang niatannya ingin hijrah memakai cadar menjadi khawatir menggunakannya. Dan tentunya dalam memaknai sesuatu hal, tidak bisa hanya melihat pada satu sudut pandang, seperti halnya anggapan orang-orang terhadap penggunaan cadar yang dinilai sebagai sesuatu yang berlebihan. Perihal menutup wajah memang bukanlah wajib, namun penggunaan cadar juga bukanlah perbuatan yang berlebihan, karena hal itu merupakan keutamaan yang juga dilakukan oleh istri-istri nabi dan sebagian sahabat wanita pada zaman itu dan setelahnya. Hanya saja penggunaan cadar memang harus diperhatikan sesuai kondisi yang bagaimana serta kapan dibolehkannya menggunakan cadar.

Penulis melihat, bahwasanya mahasiswi yang menggunakan cadar di Program Studi Pendidikan Agama Islam FITK IAIN Ambon hanya beberapa saja. Berdasarkan data yang peneliti temukan bahwasanya yang masih menggunakan cadar sebanyak 12 orang terhitung dari 
angkatan 2017 sampai dengan angkatan 2020, padahal kalau sesuai pengamatan yang pernah peneliti amati sebelum-sebelumya, jika dihitung mahasiswi yang bercadar jumlahnya bisa lebih dari segitu, namun sekarang mereka sudah tidak memakainya lagi. Ini menjadi perhatian yang menarik bagi penulis sendiri selaku peneliti untuk mencari tahu dari mereka yang masih bertahan, mencari tahu mengenai apa yang membuat mereka ingin menggunakan cadar dan juga mempertahankan memakainya hingga sekarang.

Pada dasarnya setiap individu yang ingin mencapai suatu keinginan atau tujuan dan mempertahankan tujuannya pastinya membutuhkan atau dipengaruhi oleh yang namanya motivasi. Begitu pula dalam penggunaan cadar, pastinya banyak sekali hambatan atau kendala yang dihadapi dalam setiap prosesnya, yang seiring berjalannya waktu satu per satu pun akan terseleksi dengan sendirinya, siapa yang bertahan dan siapa yang tidak lagi. Oleh tersebab itu, segala perbuatan atau aktivitas individu yang dilakukannya, baik itu penting maupun kurang penting, baik yang beresiko maupun tidak, pastinya motivasi menjadi salah satu sumber pijakannya. Motivasi yang menjadi pendorong bagi individu melakukan sesuatu sehingga ini menyangkut mengapa individu bertindak demikian dan apa yang menjadi tujuannya melakukan itu. Untuk itu, peneliti ingin berusaha mencari tahu jawaban sebenarnya apa yang membuat mereka mengambil keputusan itu. Bisa jadi ia didorong oleh kemauannya sendiri atau dari keluarga maupun lingkungan tempat tinggalnya atau yang lainnya.

\section{METODE}

Jenis penelitian ini merupakan penelitian mixed method dengan teknik pengumpulan data yang dipakai pada penelitian ini adalah wawancara, angket dan dokumentasi serta menggunakan dua teknik analisis data juga yakni secara kualitatif juga kuantitatif.

\section{HASIL}

\section{Motivasi Mahasisiwi dalam Menggunakan Cadar}


Dalam penyajian data mengenai motivasi mahasisiwi dalam menggunakan cadar yang diperoleh dari hasil wawancara dan penyebaran angket kepada 12 orang mahasiswi bercadar adalah sebagaimana berikut.

\section{a. Motivasi intrinsik bercadar}

Motivasi intrinsik ialah motivasi yang berasal dari dalam diri pribadi, yakni demi menjaga muru'ah sebagai seorang muslimah. Hal ini sejalan dengan pernyataan Ona La Tiwu, Mahasiswi Program Studi Pendidikan Agama Islam, Semester 2:

"Saya berniat menggunakan cadar dari sejak SMA kelas 1, hanya saja baru bisa terealisasikan saat masuk kuliah karena hal semacam ini tidak sepenuhnya didukung oleh pihak keluarga, ada yang mendukung dan ada yang tidak. Motivasi tersebut muncul dari dalam hati saya, saya tertarik akan penggunaan cadar yang bisa melindungi diri kita dari hal yang tidak baik (menjaga kehormatan), saya percaya bahwa dengan menggunakan cadar saya bisa mengubah pribadi yang dulu tidak baik menjadi lebih baik lagi, walau memang saya bukan terlahir dari keluarga yang begitu paham sekali tentang agama, namun bukan berarti saya tidak punya kesempatan untuk belajar menggali hal-hal ini, apalagi saya sekarang menempuh pendidikan di perguruan tinggi yang basicnya PAI, ini membuat saya makin mencoba mendalami ilmu agama saya."

Selain itu, penggunaan cadar juga merupakan bentuk upaya untuk beribadah atau menjalankan syariat Islam, seperti disampaikan oleh Diati, Mahasiswi Program Studi Pendidikan Agama Islam, Semester 8:

"Cadar itu unik yang mana fungsi cadar itu sendiri ialah melindungi perempuan dari pandangan laki-laki, dari fitnah ataupun godaangodaan lainnya. Di sini saya mengambil madzhab Syafi'i, yaitu bahwa hukum cadar wajib bagi perempuan karena seluruh bagian tubuhnya merupakan aurat sehingga motivasi saya menggunakan cadar yang pertama yaitu penjagaan terhadap muru'ah saya dan membantu menjaga pandangan dari kaum laki-laki dengan kata lain adanya keinginan untuk merasa aman, baik dari fitnah maupun perbuatan tercela lainnya. Alasan berikutnya, karena menggunakan cadar merupakan salah satu sunnah Rasulullah Shalallahu 'alaihi wassalam. Yang terakhir, insyaa Allah saya ingin menghadiahkan apa yang saya miliki hanya kepada mahram saya kelak." 
Motivasi selanjutnya ialah keinginan adanya sebuah perubahan, seperti dipaparkan oleh Rafini A Lewenusa, Mahasiswi Program Studi Pendidikan Agama Islam, Semester 8:

"Menurut saya pribadi, kalau pakai cadar itu rasanya adem, sopan dan hal ini termasuk syariat Islam juga, enak, nyaman dan terjaga. Keputusan saya bercadar pun didukung sepenuhnya oleh pihak keluarga sehingga menguatkan diri saya untuk tetap memakainya dan terlebih motivasi dalam diri saya yang mana keinginan adanya sebuah perubahan dalam hidup. Karena kalau dalam hidup tidak punya keinginan untuk berubah, rasanya hidup ini berjalannya monoton."

Selain itu, ada kedua partisipan menggunakan cadar karena motif kebutuhan. Partisipan bernama Asma Rafida Tanasy, Mahasiswi Program Studi Pendidikan Agama Islam, Semester 8 memaknai bahwa hukum cadar bukan hanya perkara sunnah, namun bagian dari kebutuhan wajib bagi ketenangan jiwanya. Sebagaimana sesuai dengan keterangannya sebagai berikut.

"Pada mulanya saya berpikir bahwa cadar merupakan suatu hal yang fanatik akan agama dan merupakan sebuah budaya dari Timur Tengah namun pada saat sudah memasuki bangku perkuliahan, saya mulai belajar bahwasanya keberadaan cadar menjadi eksistensi tersendiri sebagai kebutuhan khusus bagi perempuan. Saya selalu belajar untuk mengutamakan yang wajib. Motivasi saya yang pertama ialah bahwa menutup aurat hukumnya wajib sedangkan hukum bercadar adalah sunnah. Akan tetapi bagi saya hukum bercadar bukan hanya sebatas sunnah melainkan merupakan kebutuhan wajib. Jadi saya berpikir bahwa menjalankan sesuatu bukan hanya sebatas kewajiban namun juga kebutuhan karena memang saya benar-benar butuh hal itu karena saya merasa tenang, tidak merasa risih walau cadar selalu dipermasalahkan keberadaannya, kemudian lokasi keberadaan saya yang selalu dikelilingi dengan teman-teman yang juga sepemikiran dengan saya. Mereka juga menggunakan cadar, karena pada hakikatnya bahwa berteman dengan orang yang baik, kita akan menjadi baik tentunya. Orangtua pun mendukung, walau pada awalnya sempat risih dan kaget tapi lama kelamaan mereka juga menyetujui. Yang pada intinya saya melakukannya karena saya merasa tenang dan banyak sisi positif bagi diri saya." 
Sedangkan partisipan yang satunya lagi menjadikan cadar sebagai kebutuhan rasa aman pada dirinya. Berikut penjelasan oleh Siti Aminah Souwakil, Mahasiswi Program Studi Pendidikan Agama Islam, Semester 2:

"Sebelum menggunakan cadar saya sering merasa risih ketika berjalan di tempat umum, merasa tidak aman karena gangguangangguan kecil yang saya dapati di jalan. Setelah saya menggunakan cadar, mereka lebih menghargai saya, merasa segan ketika mereka ingin mengganggu saya dan saya memutuskan untuk menggunakan cadar karena keinginan hati saya sejak dulu, adanya niat yang terbesit kuat di diri saya sampai sekarang ini. Jadi, seberanggapan apapun mereka di luar sana tentang saya, selama hati saya tidak goyah maka saya tidak peduli apa kata mereka."

\section{b. Motivasi ekstrinsik bercadar}

Adapun faktor lain yang memperkuat keputusan menggunakan cadar ialah bersumber dari motivasi ekstrinsik, bahwa motif bercadar didasarkan atas rasa ketertarikan terhadap orang lain yang sudah lebih dulu menggunakan cadar, sehingga memancing para partisipan untuk menggunakan cadar sebagai bagian dari sunnah. Seperti yang disampaikan oleh Rukija Umagapa, Mahasiswi Program Studi Pendidikan Agama Islam, Semester 4:

"Sebenarnya sejak SMA sudah terbesit niat menggunakan cadar, namun baru terealisasikan pada saat di jenjang perkuliahan, karena baru mendapat izin dari pihak keluarga. Saya termotivasi menggunakan cadar ini pun karena kekaguman saya terhadap Ibunda Aisyah dan Fatimah Azzahra, dan juga dorongan dari lingkungan serta ada juga dari kalangan artis seperti umi pipik. Saya berpendapat bahwa cadar itu sunnah dan ketika perempuan menggunakannya akan merasa terlindungi dan membuat nyaman si pemakai karena sebelum saya pakai cadar, teman-teman lawan jenis kadang kalau bergaul sama saya itu dekat sekali kayak gak ada batasan gitu. Oleh karena saya sudah menggunakan cadar, maka ada dampak positif yang saya dapatkan dan saya berusaha mempertahankan dengan memuhasabah diri bahwa kalau saya sudah menggunakan cadar seperti ini, harus diingat tidak boleh melakukan hal-hal yang dapat menodai nama cadar itu sendiri dan berharap untuk tetap istiqamah di jalan ini." 
Ada juga faktor eksternal berupa ajakan atau saran dari orang lain, sebagaimana keterangan yang dikutip dari Dian Lestari, Mahasiswi Program Studi Pendidikan Agama Islam, Semester 8:

"Saya baru mulai memakai cadar kurang lebih tujuh bulan. Awalnya sebenarnya saya sudah termotivasi dari kakak-kakak sepupu saya. Mereka menyarankan bagusnya kalau saya mau keluar kemana gitu pakai cadar saja biar tidak diganggu sama orang asing/laki-laki. Dan waktu semester 1 pernah pakai cadar sih, tapi bertahan seminggu doang, karena mungkin kurangnya motivasi, belum terlalu diniatkan waktu itu. Akhirnya, seiring berjalannya waktu, munculah keinginan kuat terbesit dalam diri untuk menggunakan cadar karena sadar bahwa hakikatnya seorang perempuan itu alangkah baiknya kecantikannya tersembunyi saja dan ini juga ikut kemauannya seseorang (calon) agar kelak wajah saya hanya boleh ditampakkan padanya. la adalah pemberi motivasi khusus sehingga sampai sekarang ini saya masih mempertahankan cadar saya."

\section{Faktor Penghambat dan Penunjang dalam Menggunakan Cadar}

\section{a. Faktor Penghambat}

Selanjutnya, dalam mencapai suatu tujuan yang diinginkan, pada setiap prosesnya pasti ada berbagai hal yang harus dilalui oleh individu, entah itu mudah maupun beresiko. Faktor penghambat ialah segala sesuatu, hal-hal, poin-poin yang menjadi penghalang atau masalah yang membuat Untuk itu, kaitannya dengan penggunaan cadar sendiri, individuindividu yang berusaha ke arah ini tentunya menjalani berbagai hambatan, hal ini dapat dilihat dari hasil wawancara dengan mahasiswi mengenai faktor yang menghambat motivasi mereka menggunakan cadar sebagai berikut. Penjelasan dari Dian Lestari:

"Ada sebagian pihak keluarga yang tidak memberi dukungan karena mereka menganggap bahwa ketika sudah menggunakan cadar, saya tidak bisa dikenali saat sedang berpapasan di jalan"

Adapun penjelasan lain oleh Wa Ino: 
"Ibu saya kadang suka dengar orang-orang cerita kalau pakai cadar nanti susah dapat pekerjaan dan ocehan-ocehan lainnya yang keluar dari mulut para tetangga, sehingga ibu saya tidak mau kalau saya sampai menggunakan cadar"

Selain itu, Novita Karim juga menjelaskan:

"Faktor penghambatnya awalnya itu terkadang muncul dari diri sendiri, bahwasanya saya akan merasa dan terlihat berbeda, sehingga membuat saya berpikir saya nanti tidak akan merasa percaya diri saat sudah menggunakan cadar"

Sulistiani Rumata juga menjelaskan:

"Awalnya lbu saya khawatir, bahwa kalau nanti saya sudah menggunakan cadar, orang-orang akan beranggapan bahwa saya fanatik dan ibu saya menyuruh saya ketika bertemu dengan orangtua tidak perlu menggunakan cadar dan akhirnya saya saat itu memilih menggunakan masker untuk sementara waktu sampai orangtua benar-benar mengizinkan"

Mengutip keterangan dari Siti Aminah Souwakil:

"Dulu dari pihak keluarga, terutama Ibu saya belum setuju dengan hal ini dengan alasan kalau saya menggunakan cadar saya seperti orang gila/aneh nantinya, jadi jangan mengikuti hal-hal yang tidak masuk akal kayak begitu dan penggunaan cadar memang masih dianggap tabu di lingkungan sekitar (kampung saya) sehingga mereka kurang suka melihat perempuan yang mengenakan cadar"

Dan juga keterangan dari Suciyanti F Tuanaya:

"Dari keluarga menganggap penggunaan cadar merupakan bid'ah, cadar disebut aliran garis keras, pelakunya dianggap sebagai teroris dan hal negatif lainnya, sehingga membuat motivasi saya kadang down kalau dengar-dengar hal begitu"

Berdasarkan hasil wawancara di atas, faktor penghambat motivasi ada yang berasal dari dalam diri pribadi berupa kecemasan/kekhawatiran responden akan takut tidak diterimanya dalam lingkungan keluarga maupun lingkungan sekitar dan juga faktor penghambat dari luar, berbagai tanggapan negatif, cemoohan, cerita orang-orang yang tidak benar tentang cadar sehingga pihak keluarga responden pun terpengaruh akan hal itu yang membuat kurangnya ada dukungan keluarga dalam memotivasi anak-anak mereka menggunakan cadar. 


\section{b. Faktor Penunjang}

Adalah segala sesuatu yang dapat membantu, mendukung, memberi efek positif untuk mencapai tujuan yang diinginkan. Faktor penunjang motivasi dalam menggunakan cadar sebagaimana hasil wawancara dengan beberapa mahasiswi sebagai berikut:

Megawati Sanmas:

"Motivasi saya menggunakan cadar ini didukung penuh oleh pihak keluarga dan juga teman-teman di lingkungan saya, mungkin karena memang mereka sudah paham arti penting dari penggunaan cadar itu sendiri, dan hukumnya bagaimana sehingga jika memang hal ini baik pada diri saya, maka dipandang baik juga oleh keluarga saya"

Keterangan dari Wa Ino:

"Ketika ibu saya memarahi saya menggunakan cadar, kakak saya selalu berusaha untuk beri pemahaman sebagai bentuk pembelaan terhadap saya dan ditambah dengan dukungan dari teman-teman saya"

Selain itu, Novita Karim menjelaskan:

"Salah satu faktornya ialah karena seringnya menonton ceramah tentang kematian, dari sini saya selalu dibuat sadar bahwa esok ketika telah meninggalkan dunia ini, yang kita tinggalkan adalah amal ibadah dan semua hal akan dipertanggungjawabkan dan faktor lainnya dukungan dari orangtua"

Penjelasan dari Siti Aminah Souwakil:

"Menonton syiar Islam tentang penggunaan cadar dan mencari tahu hukum cadar itu sendiri. Ini menjadi motivasi pendukung saya."

Dan juga mengutip keterngan dari Diati:

"Faktor pendukung motivasi saya menggunakan cadar yaitu dari beberapa sahabat, sepupu dan lingkungan pertemanan saya, mereka selalu memberi nasehat, mengajak untuk mari hijrah bersama-sama."

Berdasarkan hasil wawancara di atas, faktor penunjang motivasi dalam menggunakan cadar yaitu adanya kesadaran individu akan hakikat tujuan sebenarnya diciptakan manusia ke dunia ini, dukungan dari orangtua yang memang sudah paham akan cadar, dukungan dari saudara maupun teman-teman yang selalu berusaha mengajak kepada hal-hal 
positif serta tontonan syiar/kajian Islami yang menambah semangat para responden untuk menggunakan cadar.

Selanjutnya, dari hasil penyebaran kuesioner kepada 12 orang mahasiswi bercadar, kuesioner yang kembali berjumlah 11, sehingga data dari hasil kuesioner yang dapat diolah ialah 11 kuesioner maka peneliti dapat mengetahui tingkat motivasi bercadar sebagai berikut:

TABEL.1

Rekapitulasi Data Persentase dari Hasil Tes tentang Tingkat Motivasi Mahasiswi Program Studi Pendidikan Agama Islam Fakultas IImu Tarbiyah dan Keguruan IAIN Ambon dalam Menggunakan Cadar

\begin{tabular}{|c|c|c|c|c|c|c|c|c|c|c|}
\hline \multirow{3}{*}{$\begin{array}{c}\text { No } \\
\text { Item }\end{array}$} & \multicolumn{8}{|c|}{ Persentase Alternativ Jawaban } & \multirow{2}{*}{\multicolumn{2}{|c|}{ Jumlah }} \\
\hline & \multicolumn{2}{|c|}{$\begin{array}{l}\text { Sangat } \\
\text { Setuju }\end{array}$} & \multicolumn{2}{|c|}{ Setuju } & \multicolumn{2}{|c|}{$\begin{array}{l}\text { Kurang } \\
\text { setuju }\end{array}$} & \multicolumn{2}{|c|}{$\begin{array}{l}\text { Tidak } \\
\text { setuju }\end{array}$} & & \\
\hline & $\mathbf{F}$ & $\mathbf{P}$ & $\mathbf{F}$ & $\mathbf{P}$ & $\mathbf{F}$ & $\mathbf{P}$ & $\mathbf{F}$ & $\mathbf{P}$ & $\mathbf{F}$ & $\mathbf{P}$ \\
\hline 1 & 9 & $\begin{array}{c}81,82 \\
\%\end{array}$ & 2 & $18,18 \%$ & 0 & $0 \%$ & 0 & $0 \%$ & 11 & $100 \%$ \\
\hline 2 & 11 & $100 \%$ & 0 & $0 \%$ & 0 & $0 \%$ & 0 & $0 \%$ & 11 & $100 \%$ \\
\hline 3 & 7 & $\begin{array}{c}63,64 \\
\%\end{array}$ & 4 & $36,36 \%$ & 0 & $0 \%$ & 0 & $0 \%$ & 11 & $100 \%$ \\
\hline 4 & 10 & $\begin{array}{c}90,90 \\
\%\end{array}$ & 1 & $9,10 \%$ & 0 & $0 \%$ & 0 & $0 \%$ & 11 & $100 \%$ \\
\hline 5 & 6 & $\begin{array}{c}54,55 \\
\%\end{array}$ & 5 & $45,45 \%$ & 0 & $0 \%$ & 0 & $0 \%$ & 11 & $100 \%$ \\
\hline 6 & 4 & $\begin{array}{c}36,36 \\
\%\end{array}$ & 7 & $63,64 \%$ & 0 & $0 \%$ & 0 & $0 \%$ & 11 & $100 \%$ \\
\hline 7 & 4 & $\begin{array}{c}36,36 \\
\%\end{array}$ & 1 & $9,10 \%$ & 3 & $\begin{array}{c}27,27 \\
\%\end{array}$ & 3 & $\begin{array}{c}27,27 \\
\%\end{array}$ & 11 & $100 \%$ \\
\hline 8 & 8 & $\begin{array}{c}72,73 \\
\% \\
\end{array}$ & 3 & $27,27 \%$ & 0 & $0 \%$ & 0 & $0 \%$ & 11 & $100 \%$ \\
\hline 9 & 3 & $\begin{array}{c}27,27 \\
\%\end{array}$ & 4 & $36,36 \%$ & 4 & $\begin{array}{c}36,36 \\
\%\end{array}$ & 0 & $0 \%$ & 11 & $100 \%$ \\
\hline 10 & 0 & $0 \%$ & 5 & $45,45 \%$ & 0 & $0 \%$ & 6 & $\begin{array}{c}54,55 \\
\%\end{array}$ & 11 & $100 \%$ \\
\hline 11 & 4 & $\begin{array}{c}36,36 \\
\%\end{array}$ & 7 & $63,64 \%$ & 0 & $0 \%$ & 0 & $0 \%$ & 11 & $100 \%$ \\
\hline 12 & 11 & $100 \%$ & 0 & $0 \%$ & 0 & $0 \%$ & 0 & $0 \%$ & 11 & $100 \%$ \\
\hline $\begin{array}{c}\text { Jumla } \\
\mathrm{h}\end{array}$ & 77 & $700 \%$ & 39 & $\begin{array}{c}354,55 \\
\%\end{array}$ & 7 & $\begin{array}{c}63,63 \\
\%\end{array}$ & 9 & $\begin{array}{c}81,82 \\
\%\end{array}$ & 11 & $100 \%$ \\
\hline
\end{tabular}

Dari tabel rekapitulasi di atas dapat diketahui bahwa: 
Alternatif jawaban sangat setuju sebanyak $\quad: 77$

Alternatif jawaban setuju sebanyak $\quad: 39$

Alternatif jawaban kurang setuju sebanyak $\quad: 7$

Alternatif jawaban tidak setuju sebanyak: 9

Maka diperoleh hasil:

$\begin{array}{llllll}\text { Sangat Setuju } & & : 77 & \mathrm{x} & 4 & 4 \\ \text { Setuju } & : 39 & \mathrm{x} & 3 & =117 \\ \text { Kurang setuju } & & : 7 & \mathrm{x} & 2 & =14 \\ \text { Tidak setuju } & : \underline{9} & \times & 1 & \underline{=9} & \\ \text { Jumlah } & : 132 & & & & 455\end{array}$

Maka diperoleh nilai:

$F=455$

$N=132 \times 4=528$

Selanjutnya untuk mengetahui tingkat motivasi mahasiswi dalam menggunakan cadar dapat diperoleh dengan rumus:

$$
\begin{gathered}
\mathrm{P}=\frac{F}{N} x 100 \\
\mathrm{P}=\frac{455}{528} x 100=\frac{45.500}{528}=86,17 \%
\end{gathered}
$$

Dari rekapitulasi data hasil kuesioner di atas dapat diungkapkan bahwa motivasi mahasiswi prodi PAl dalam menggunakan cadar dipengaruhi oleh dua faktor yaitu faktor intrinsik (mastery goal dan need for achivment) dan faktor ekstrinsik (harapan otoritas dari keluarga, teman, pendidikan serta fear of failur) dengan besar persentase adalah delapan puluh enam koma tujuh belas persen dan termasuk pada kategori "Sangat Tinggi", karena hasil perhitungan diperoleh berada di antara delapan puluh satu persen sampai dengan seratus persen. Ini artinya bahwa mereka mencoba menggunakan cadar dan tetap mempertahankan cadarnya karena peran andil motivasi mereka yang terbilang sangat tinggi, baik timbul dari faktor motivasi internal maupun eksternal. 


\section{PEMBAHASAN}

\section{Analisa Data tentang Motivasi Mahasiswi Program Studi Pendidikan Agama Islam FITK IAIN Ambon dalam Menggunakan Cadar}

Berdasarkan hasil wawancara yang dilakukan terhadap mahasiswi Program Studi Pendidikan Agama Islam yang bercadar, maka dapat diketahui bahwa:

1) Cadar sebagai bentuk perlindungan diri/kehormatan diri (muru'ah dan izzah) bagi hakikat seorang wanita muslim

2) Cadar sebagai bagian dari menjalankan salah satu syari'at Islam yaitu mengikuti sunnah Rasulullah Shalallahu 'alaihi wassalam

3) Dapat menumbuhkan rasa aman, nyaman dan tenang bagi si pemakai

4) Menyadarkan kita agar selalu ingat bahwa ada batasan dalam pergaulan dengan lawan jenis/bukan mahram

5) Membantu menjaga pandangan laki-laki

6) Mempercantik diri dengan menutup semua pintu fitnah

7) Alternativ untuk lebih mendekatkan diri kepada Allah Subhananu wa ta'ala

8) Menimbulkan kepercayaan diri

9) Mengurangi kerusakan moral

Dalam penelitian ini, para partisipan sudah mengetahui dan menyadari secara tekstual dasar hukum bercadar, artinya mereka paham bahwa hukum cadar di kalangan para ulama ada yang menganggap sunnah, mubah, makruh, bahkan wajib. Namun begitu, hal yang paling utama bagi para partisipan ialah benar-benar menyadari bahwa wajib hukumnya bagi setiap wanita muslimah mengenakan jilbab/hijab bukan atas dasar karena berstatus sedang menempuh pendidikan sebagai 
mahasiswi di IAIN Ambon, akan tetapi jatuh wajibnya ini bagi semua wanita yang sudah baligh.

Sebagaimana firman Allah mengenai hukum wajibnya berjilbab dalam surah al-ahzab ayat 59 berikut ini:

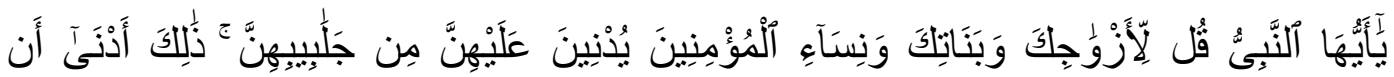

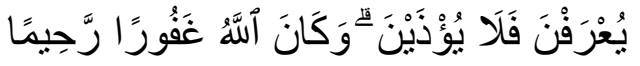

Terjemahnya: Wahai Nabi! Katakanlah kepada istri-istrimu, anak-anak perempuanmu dan istri-istri orang mukmin, "Hendaklah mereka menutupkan jilbabnya ke seluruh tubuh mereka." Yang demikian itu agar mereka lebih mudah untuk dikenali, sehingga mereka tidak diganggu. Dan Allah Maha Pengampun, Maha Penyayang.

Sebagaimana juga Allah Subhanahu wa ta'ala telah berfirman dalam surah An Nur ayat 31:

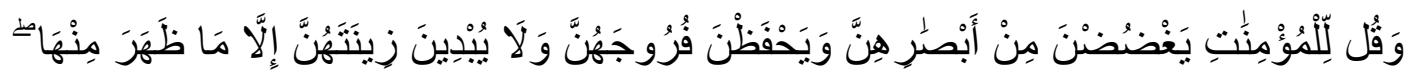

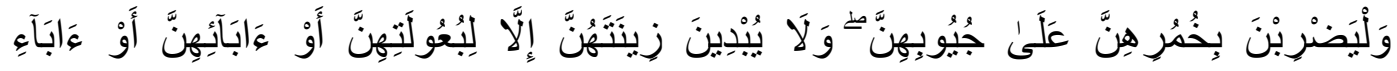

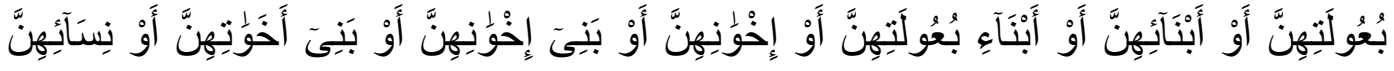

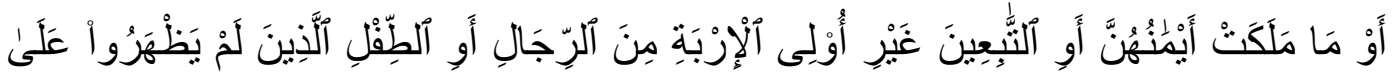



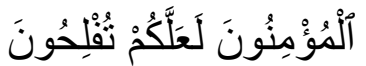

Terjemahnya: Dan katakanlah kepada para perempuan yang beriman, agar mereka menjaga pandangannya, dan memelihara kemaluannya, dan janganlah menampakkan perhiasannya (auratnya), kecuali yang (biasa) terlihat. Dan hendaklah mereka menutupkan kain kerudung ke dadanya, dan janganlah menampakkan perhiasannya (auratnya), kecuali kepada suami mereka, atau ayah mereka, atau ayah suami mereka, atau putraputra mereka, atau putra-putra suami mereka, atau saudara-saudara laki mereka, atau putra-putra saudara laki-laki mereka, atau putra-putra saudara perempuan mereka, atau para perempuan (sesama Islam) mereka, atau hamba sahaya yang mereka miliki, atau para pelayan lakilaki (tua) yang tidak mempunyai keinginan (terhadap perempuan), atau anak-anak yang belum mengerti tentang aurat perempuan. Dan janganlah mereka menghentakkan kakinya agar diketahui perhiasan yang mereka sembunyikan. Dan bertobatlah kamu semua kepada Allah, wahai orangorang yang beriman, agar kamu beruntung. 
Dapat diketahui bahwasanya berdasarkan ayat di atas tidak hanya dijelaskan tentang wajibnya menutup aurat menggunakan jilbab, tapi juga menjelaskan apa saja batasan-batasan yang merupakan aurat, yakni seluruh tubuh wanita kecuali wajah dan telapak tangan.

Masih dalam pembahasan yang sama tentang aurat, para ulama pun memiliki pendapatnya masing-masing dalam mengkategorikan perihal aurat. Ada beberapa ulama mengatakan bahwa seluruh tubuh wanita dari ujung kaki sampai kepala merupakan aurat kecuali area mata, sedangkan wajah ialah aurat yang harus ditutupi agar kemungkinan hal-hal yang tidak diinginkan bisa dihindari.

Cadar/niqab bisa dijadikan alternativ bagi wanita muslimah yang ingin menutup wajahnya demi menghindari hal-hal yang tidak diinginkan. Penggunaan cadar memang tidak dijelaskan dalam al-Qur'an mengenai apa hukumnya, namun hal ini juga tidak menjadikan cadar sebagai sesuatu yang salah untuk ditiru, karena jelas pada zaman Rasulullah Saw para istri-istri nabi ada yang mengenakan cadar. Ini menjadi sumber pijakan para respoden untuk menerapkan sunnah Rasul yang menjadi bagian dalam syari'at Islam.

Eksistensi cadar sendiri, selain sebagai penutup wajah banyak juga dampak positif yang didapatkan. Mengambil simpulan dari laporan hasil wawancara para responden, bahwa dengan menggunakan cadar kita sebagai wanita muslimah yang kodratnya harus terjaga dari fitnah, bisa lebih sadar akan batasan kita ketika bergaul dengan teman lawan jenis, bahkan lawan jenis bisa lebih menghargai dan segan jika ingin berdekatan dengan kita, dan selain dari diri kita sendiri yang punya kesadaran akan batasan itu, dengan cadar kita juga bisa membuat orang lain sadar akan batasan mereka tanpa kita mengatakannya secara langsung.

Wanita muslimah yang mencoba belajar menggunakan cadar pun tidak terlepas dari berbagai hambatan atau rintangan, sehingga ada yang sudah tidak sanggup melaluinya yang akhirnya berhenti menggunakan 
cadar, maka alangkah bersyukurnya para wanita yang masih mempertahankan cadarnya hingga sekarang ini, apalagi zaman yang semakin penuh dengan tipu daya. Para wanita yang masih menggunakan cadar, sebenarnya tidak terlepas dari motivasinya juga. Kita perlu perhatikan bahwa pengaruh motivasi dalam hidup ini menjadi hal yang penting demi membangun kehidupan ke arah yang lebih baik. Motivasi dalam menggunakan cadar bisa muncul dari mana saja, entah itu dari dukungan keluarga, keterpanggilan niat hati yang kuat atau bahkan mengikuti sosok yang menjadi panutan.

Di dalam agama Islam, kedudukan wanita sangat dimuliakan dan wanita merupakan sosok yang harus diberi perhatian lebih dari segi pengetahuan agama karena wanita dengan agama yang baik kelak akan melahirkan generas-generasi yang baik pula bahkan eksistensi wanita sudah dijelaskan secara jelas dalam al-Qur'an dengan nama surahnya sendiri yaitu An-Nisa sehingga bagi wanita yang sadar hal ini, ia akan berusaha belajar membenahi diri, menjaga muru'ah, izzah maupun iffahnya dan semata-semata mencari ridha Allah Subhanahu wa ta'ala.

2. Analisa Data tentang Faktor Penunjang dan Penghambat Motivasi Mahasiswi Program Studi Pendidikan Agama Islam FITK IAIN Ambon dalam Menggunakan Cadar

a. Faktor penunjang

Adalah segala sesuatu yang dapat membantu, mendukung, memberi efek positif untuk mencapai tujuan yang diinginkan. Faktor penunjang dapat dilihat dari sisi internal dan juga eksternal.

1) Faktor penunjang motivasi dalam menggunakan cadar dari sisi internal, yakni dari dalam individu sendiri sebagai berikut:

a) Poin tentang "kematian". Bahwasanya kematian adalah sebaik-baiknya pengingat, ini membuat individu selalu dibuat sadar bahwa kehidupan di 
dunia hanya sementara dan tujuan manusia diciptakan hanyalah untuk beribadah kepada Allah, maka alangkah ruginya jika kita tidak berusaha mengumpulkan pundi-pundi amal ibadah untuk bekal di akhirat-Nya kelak.

b) Selain itu dukungan keluarga juga menjadi salah satu poin penting di sini, ada keluarga yang memberi dukungan penuh, karena mereka paham bahwa penggunaan cadar merupakan bagian dari syari'at Islam.

2) Faktor eksternal, seperti ajakan-ajakan hijrah dari teman-teman, mereka selalu mencoba memberi nasehat dan dukungan positif. Selain itu, tontotan tentang cadar yang ada di sosial media juga menjadi salah satu faktor penunjang motivasi mereka dalam menggunakan cadar, seperti ceramah tentang hukum penggunaan cadar itu sendiri ataupun sosok-sosok bercadar yang dikagumi.

b. Faktor penghambat

Merupakan segala sesuatu, hal-hal, poin-poin yang menjadi penghalang atau masalah yang membuat lambat atau bahkan ketidakberhasilan ketercapaian tujuan yang diinginkan. Faktor ini juga dilihat dari dua sisi, yakni internal dan eksternal.

1) Faktor internal

a) Awalnya berpikir jika sudah menggunakan cadar nantinya membuat diri menjadi terlihat berbeda dan dibuat khawatir tentang apa yang selanjutnya terjadi atau apa pendapat orang lain nantinya, sehingga 
timbulnya keresahan/keraguan dalam diri sendiri untuk mau tidaknya menggunakan cadar.

b) Selanjutnya kurangnya dukungan keluarga, mereka menganggap bahwa penggunaan cadar merupakan bid'ah, cadar disebut aliran garis keras, pelakunya dianggap sebagai teroris dan hal negatif lainnya. Selain itu, pihak keluarga berpikir bahwa ketika sudah menggunakan cadar, nantinya tidak bisa mengenali anggota keluarganya saat sedang berpapasan di jalan.

\section{2) Faktor eksternal}

a) Isu-isu yang kurang bagus yang diceritakan oleh orang-orang di luar tentang cadar, terlebih di lingkungan sekitar tempat tinggal, seperti kalau pakai cadar nanti susah dapat pekerjaan sehingga membuat sebagian pihak keluarga terutama orangtua ragu untuk mengizinkan anak mereka menggunakan cadar.

b) Karena pada dasarnya faktor lingkungan (tempat tinggal) yang memang masih menganggap tabu terhadap penggunaan cadar itu sendiri membuat niat menggunakan cadar kadang sedikit susah untuk realisasikan, para pengguna harus mampu beradaptasi dengan suasana yang ada. 


\section{KESIMPULAN}

Berdasarkan hasil penelitian yang telah penulis lakukan di IAIN Ambon Fakultas Ilmu Tarbiyah dan Keguruan Program Studi Pendidikan Agama Islam, disimpulkan bahwa:

a. Motivasi mahasiswi dalam menggunakan cadar antara lain sebagai berikut:

1) Adanya niat yang kuat demi perlindungan diri/kehormatan diri (muru'ah dan izzah) bagi hakikat seorang wanita muslim.

2) Mencoba belajar menjalankan salah satu syari'at Islam yaitu mengikuti sunnah Rasulullah Shalallahu 'alaihi wassalam.

3) Adanya rasa aman, nyaman, tenang, dan rasa percaya diri bagi si pemakai.

4) Karena ada batasan dalam pergaulan dengan lawan jenis/bukan mahram yang harus dijaga.

5) Keinginan membantu menjaga pandangan.

6) Keinginan mempercantik diri dengan menutup semua pintu fitnah.

7) Ingin lebih mendekatkan diri kepada Allah Subhananu wa ta'ala.

8) Adanya saran dan ajakan dari sanak saudara/teman/orang lain.

9) Kekaguman terhadap sosok idola bercadar.

Selanjutnya melalui data kuesioner yang telah diolah menggunakan analisa kuantitatif mengenai tingkat motivasi mahasiswi prodi PAI dalam menggunakan cadar yang termuat oleh dua faktor yaitu faktor intrinsik mastery goal dan need for achivment) dan faktor ekstrinsik (harapan otoritas dari keluarga, teman, pendidikan serta fear of failur), menunjukkan keseluruhan hasil persentase berada pada nilai $86,17 \%$ dan termasuk pada kategori "Sangat Tinggi".

b. Adapun faktor penunjang dan penghambat motivasi dalam menggunakan cadar, yaitu:
a. Faktor penunjang 
1) Pribadi selalu teringat tentang kematian yang menjadi hal utama dalam mengumpulkan pundi-pundi amal ibadah.

2) Adanya dukungan positif (diberi kebebasan untuk menggunakan cadar) oleh keluarga/sanak saudara lainnya.

3) Lingkungan sekitar/lingkungan pertemanan yang selalu memberi motivasi.

4) Mengikuti atau menonton ceramah/kajian/syiar tentang penggunaan cadar.

b. Faktor penghambat

1) Adanya rasa was-was dalam diri karena takut dikucilkan.

2) Selain itu, keluarga juga ada yang tidak mengizinkan karena menganggap cadar adalah sesuatu hal yang tidak masuk akal, aliran garis keras dan khawatir tidak bisa saling mengenal anggota keluarganya ketika berpapasan di jalan.

\section{DAFTAR PUSTAKA}

[1] Abdus Salam Thawilah, Abdul Wahhab. Panduan Berbusana Islami, terj. Saefudin Zuhri, Jakarta: Almahira, 2007.

[2] Agama, Fakta. Islam On The Spot. Jakarta: Wahyu Qolbu, 2015.

[3] Ali, Nujood dan Delphine Minoui. Nama Saya Nujood Usia 10 dan Janda, terj. Lulu Fitri. Jakarta: PT Pustaka Alvabet, 2019.

[4] Al-Qur'an Terjemah Al-Hasib. Jakarta Pusat: Samad.

[5] A Octavia, Shilphy. Motivasi Belajar dalam Perkembangan Remaja. Yogyakarta: Deepublish, 2020.

[6] Dayana, Indri dan Juliester Marbun. Motivasi Kehidupan. Medan: Guepedia, 2018.

[7] Efendi, Rinja dan Delita Gustriani. Manajemen Kelas di Sekolah Dasar. Jawa Timur: Qiara Media, 2020.

[8] E Slavin, Robert. Educational Psychology Theory And Practice. Boston MA: Pearson Education, 2006.

[9] Hanafi, Halid dkk. Profesionalisme Guru dalam Pengelolaan Kegiatan Pembelajaran di Sekolah. Yogyakarta: Deepublish, 2018.

[10] Hasim, Djamil. Pengaruh Kepemimpinan, Motivasi dan Iklim Kerja Terhadap Kinerja Pegawai pada Dinas Kesejahteraan Sosial Kabupaten Biak Numfor. Pasuruan: CV. Qiara Media, 2019.

[11] Hilmi, Ahmad. Hukum Cadar Bagi Wanita. Jakarta Selatan: Rumah Fiqih Publishing, 2019. 
[12] https://dalamislam.com/hukum-islam/wanita/manfaat-menggunakan-cadar, diakses pada tanggal 26 Juni 2020.

[13] https://larahijab.com/khimar-adalah-kain-penutup-aurat-yang-syarii/ diakses pada tanggal 23 Februari 2021.

[14] https://kbbi.web.id/cadar, diakses pada tanggal 24 Juni 2020.

[15] http://rasto.staf.upi.edu/2016/03/14/proses-motivasi-menurut-paraahli/\# ftnref5, diakses pada tanggal 11 Juni 2020.

[16] https://republika.co.id/berita/p52h7m396/kala-curiga-menghantui-cadar-dikampus-islam.

[17] https://womantalk.com/fashion/articles/jangan-keliru-ini-bedanya-hijabjilbab-niqab-cadar-burqa-dan-khimar-xvMvJ diakses pada tanggal 23 Februari 2021.

[18] Lubis, Amany dkk. Ketahanan Keluarga dalam Perspektif Islam, Pandangan Komisi Pemberdayaan Perempuan, Remaja dan Keluarga Majelis Ulama Indonesia. Jakarta: Pustaka Cendikiawan Muda, 2018.

[19] Mariana, Anna. Ketika Allah Swt Lebih Menyayangi Wanita. Bandung: Ruang Kata Imprint Kawan Pustaka, 2011.

[20] Mujahidin. 'Cadar: Antara Ajaran Agama Dan Budaya', JUSPI (Jurnal $\begin{array}{lllll}\text { Sejarah Peradaban } & \text { Islam), } & 3.1 & \text { (2019), } & 11\end{array}$ <https://doi.org/10.30829/juspi.v3i1.3142>.

[21] Muthahhari, Murthada. Cadar Tuhan Duduk Perkara Hijab Perempuan, terj. Nashib Mustafa. Jakarta: Citra, 2012.

[22] Muslimah, Genta. Muslimah Antibaper. Sidoarjo: Genta Group Production, 2020.

[23] Mózo, Beatriz Sanchez, ‘済無No Title No Title', Journal of Chemical Information and Modeling, $53.9 \quad$ (2017), $1689-99$ https://doi.org/10.1017/CBO9781107415324.004

[24] Parnawi, Afi. Psikologi Belajar. Yogyakarta: Deepublish, 2019.

[25] Qasthalani, M. 'Konsep Hijab Dalam Islam M. Qasthalani STIT Agus Salim Metro', 4.01, 143-57.

[26] Ulfha. Cinta Suci Zalyka. Cilegon: Guepedia, 2018.

[27] Shihab, Quraish. Jilbab Pakaian Wanita Muslimah. Jakarta: Lentera Hati, 2004.

[28] Sri Mendari, Anastasya dan Suramaya Suci Kewal. Motivasi Belajar pada Mahasiswa, Jurnal Pendidikan Akutansi Indonesia, 2015, 13(2).

[29] Sunadi, Lukman. 'Pengaruh Motivasi Belajar dan Pemanfaatan Fasilitas Belajar Terhadap Prestasi Belajar Siswa pada Mata Pelajaran Ekonomi Kelas XI IPS di SMA Muhammadiyah 2 Surabaya', Jurnal Pendidikan Ekonomi, 2010, 1-19.

[30] Sukendro, Gatot dkk. Agustus 2016. "Nilai Fetisisme Komoditas Gaya Hijab (Kerudung Dan Jilbab) Dalam Busana Muslimah". Jurnal Sosioteknologi. Vol. 15, No 2, hlm. 243 from https://media.neliti,com/media/publication/131781-none-9a83d205.pdf

[31] Umam, Ahmad Khairul. 'Pandangan Mahasiswi IAIN Palangka Raya Yang Bercadar Tentang Hukum Memakai Cadar', 2019. 
al-iltizam: Jurnal Pendidikan Agama Islam, Vol. 6, No.2, Desember 2021

[32] Utama, Topik 'Topik Utama Cadar, Media, Dan Identitas Perempuan Muslim Oleh : Lintang Ratri'. 